\title{
An Assessment of the Impact of Business Plan Competitions on Enterprise Development in Kenya: A Case Study of Chora Bizna Enablish LaunchPad
}

\author{
Sylvance Mboha, MA \\ Adjunct Lecturer, Pan Africa Christian University, Kenya
}

Doi: 10.19044/esj.2018.v14n10p390 URL:http://dx.doi.org/10.19044/esj.2018.v14n10p390

\begin{abstract}
The purpose of the study was to establish the impact of business plan competitions (BPCs) on enterprise development as measured by number of new ventures created and sustained, number and value of jobs created, revenue turnover growth and value of assets. The BPC was dubbed "Chora Bizna Enablis LaunchPad". The study used a quasi-experimental design. The target population was the top 100 national finalists who undertook a one week intensive training at Multimedia University. The accessible population was 52 finalists, of which 45 successfully responded. This number was used as the test group. A matched sample of non-participants was drawn from small business owners in Nairobi County. Data was analysed using SPSS. The results revealed that out of the 45 national finalists interviewed, 35 went ahead to implement their business plans, creating employment for 210 people who earned a total monthly salary of over 4 million Kenya shillings. Their enterprises were posting an aggregate of 13.8 million Kenya shillings in revenue every month, and the entrepreneurs reported an accumulated value of assets estimated at a total of 518 million Kenya shillings. On average, each participant in the BPC employed more than twice the number of employees reported by non-participants and disbursed nearly double the average total monthly salaries reported by non-participants. Similarly, the average revenue of BPC participants quadrupled that of non-participants. BPC participants also reported significantly higher average value of accumulated assets compared to non-participants. Therefore, such competitions are effective for fostering enterprise development and more should be held.
\end{abstract}

Keywords: Enterprise Development, Human Capital, Social Capital, Economic Capital 


\section{Introduction}

The fostering of enterprise development through business plan competitions (BPCs) is generating a lot of interest from both practitioners and the academia alike. Enterprise development in this context is understood as "the intervention in the free market economic system for the purpose of assisting entrepreneurs in creating and growing successful new businesses" (Durr \& Hill, 2006, p.214). Existing statistics claim that three out of five startup businesses close shop within a few months of operation (Bowen, Morara, \& Mureithi, 2009), a problem which is partly attributed to lack of a business plan (Gachiri, 2009). This suggests that small enterprise owners need training in a number of entrepreneurial skills to create and manage sustainable business ventures. According to Russell, Atchison and Brooks (2008), BPCs comprise a series of structured workshops offered within the calendar of the competition aimed at complementing contestants' disciplinary knowledge in order to assist them acquire the basic skills to develop a business plan from the initial bright idea to a fully developed document that maps and validates the path of the idea to its launch and running of the business. BPCs as a concept for fostering enterprise development through such workshops, is therefore increasingly demanding the attention of, and becoming recognized and promoted by public policy makers (Libecap, 2009), the private sector (London, Hart, \& Kacou, 2011), Non-Governmental Organizations (Stevenson, 2010) and institutions of higher education (Organization for Economic Cooperation and Development, 2010; Zhang \& Zhang, 2011).

Business Plan Competitions as a practice is ubiquitous in most developed countries such as the USA (Crainer \& Dearlove, 2000) and Europe (Riviezzo, De Nisco, \& Napolitano, 2012), and is fast proliferating within developing nations in Asia (Wong, 2011) and Africa (House-Soremenkun \& Falola, 2011). A Google search conducted by Lange, Mollov, Pearlmutter, Singh and Bygrave (2007) showed that there were 1.86 million hits for "business plan" and "competition" or "competitions", implying the extent of its proliferation globally. In countries such as China, BPCs are considered as an effective new way of obtaining practical knowledge compared to sitting and listening to professors in the old education system (Fayolle, 2004); and in some states in the USA, there are even prison entrepreneurship programs that provide in-prison BPCs targeting in-mates (Jaishankar, 2009).

In Kenya, interventions for the purposes of assisting entrepreneurs have taken on an unprecedented interest by stakeholders in the education, government and private sectors in recent years. To foster an entrepreneurship culture, ministries such as the then Youth Affairs and Industrialization, currently Ministry of Public Service, Youth and Gender Affairs, teamed up with bodies like the World Bank to rekindle interest in business plan writing which is seen as the anchor of business success (Gachiri, 2009). The then 
Ministry of Youth Affairs (MOYAS) had been spearheading the implementation of several youth policies and programs dealing with issues such as entrepreneurship, employment, training and education ( $\mathrm{Njogu}, 2013$ ). Of all the programs, the entrepreneurship component received more attention and support which culminated into the broadening of focus to include training and mentoring, business incubation and holding a BPC (Njogu, 2013).

The 2009 Kenya National Business Plan Competition dubbed "ChoraBizna Enablis LaunchPad" which was the focus of this study had two phases. The first Phase included the launch to create awareness and training workshops which took place countrywide across 16 towns. Following the training workshops, each participant then had to hand in a business plan which was judged by business leaders and entrepreneurship consultants in search of the top business plans in terms of innovativeness, originality, sustainability and growth potential (Were, 2009). In the second phase, the entrants who were ranked top 100 National Finalists underwent another three days of training in Nairobi hosted at the Multimedia University of Kenya (Were, 2009). Winners in this competition took away an estimated 6 million shillings in cash and prizes (Enablis Entrepreneurial Network East Africa, 2013). Clearly, BPCs often involve millions of money in organization and awards. However, despite the expenditure of colossal amounts of time and money in their planning and execution, it is not clear from existing literature whether the investment in BPCs translate into enterprise development which is the primary reason for such competitions.

A review of literature suggests that there is a paucity of research that attempt to determine the impact that BPCs have on entrepreneurship and enterprise development, and the few published studies return mixed results. For example, Russell et al.'s (2008) case study of the MI50K Entrepreneurship Competition, a popular BPC program in the USA, reported that the impact of its competition included: the birth of over 60 companies with an aggregate value of $\$ 10.5$ billion dollars, which generated 1,800 jobs and received $\$ 175$ million dollars in Venture Capital funding. On the other hand, in their research on the efficiency and effectiveness of BPCs, Fayolle and Klandt (2006) concluded that with some training, many people could probably write a credible business plan, although only a few could probably build a business. They found that business plans with better evaluation scores were not significantly more likely to correspond to successful businesses.

The inconsistent results from past studies seem to fuel controversial advice in existing entrepreneurship literature (Rosseau, 2012). For example, while its proponents such as Leadbeater and Oakley (2001) think that writing business plans should become a national pastime, cynics like Gumpert (2003) advises people to burn their business plans altogether. Therefore, without compelling empirical evidence, universities, NGOs, government agencies and 
the private sector will continue to participate in activities and events whose value for money remain questionable. In Kenya, there is a shortage of research that has been documented on the impact of BPC on enterprise development. A similar study in Kenya was conducted by Letting and Muthoni (2013) whose research focused on the effects of business planning in the sustainability of the Micro, Small and Medium Enterprises based on the case of a BPC conducted by Kenya Institute of Management. Although their findings established that those entrepreneurs who had business plans had sustainable businesses, this relationship was not supported by statistical evidence, thus providing a study gap.

\section{Research Objectives}

The study sought to achieve the following objectives:

i) Assess the impact of human capital development aspect of business plan competitions on enterprise development in Kenya.

ii) Assess the impact of social capital creation through participation in business plan competitions on enterprise development in Kenya.

iii) Evaluate the impact of economic capital offered in business plan competitions on enterprise development in Kenya.

\section{Literature Review}

Scholarly literature on the concept of BPC is propagated from the theoretical lenses of human capital, economic capital and social capital frameworks.

The term human capital has been defined as "the propensity of a person or group to perform behavior that is valued from an income earning perspective by an organization or society" (Smith-Hunter, 2006 p. 31). According to Hulsink and Dons (2008), human capital is a well-established concept in economic literature concerning entrepreneurship. Within the context of BPCs, human capital developments is characterized by the impartation of business plan writing skills, pitching and presentation skills and the enhancement of self-confidence.

An empirical study conducted by Etemad (2004) showed that many people who prepare for and compete in BPCs go on to start their own new ventures, regardless of whether they win the competition or not. In contrast, a study of entrepreneurship education in Asia conducted by Kelley and Thomas (2011) established that most business plans disappear after the competition. The authors provided several reasons for this. First, the plans may not be practical in real life, in the opinion of the judges. Secondly, although the entrants may do the marketing research and analysis, their ideas exist only in their imaginations, with little evidence that they can be supported from the perspective of actual business practice or experience. They also postulated that 
the plans were still far from showing evidence that they would succeed in business and investors also did not think it was reasonable to invest large amounts of money in pure concept projects as indicated in their respective business plans. The literature on the benefits of business plan writing showed that research is not conclusive on the added human capital value of business plan writing as a skill.

Another skill learnt in a BPC is how to pitch your business. According to Kaputa (2012), the business pitch is what makes your business unique, special and needed; one that you use with clients, investors, the media, and employees, describing the essence of what your business is all about. In concert, Wankel (2010) argues that if you are good at an business pitch - a concise way of describing what your company does (Schwerdtfeger, 2011), you will be very well prepared to pitch your business convincingly at a moment's notice. Wankel (2010) opined that with practice, one would probably also do well in a BPC, which is one way that entrepreneurs find seed capital to get started. As former director and judge of a BPC, Rabb (2009) realized that judges did not rate the viability of the business model but the ability of the contestant to advocate for her venture in clear, substantive, and compelling ways. Russell et al. (2008) however held the view that a difficult component for participants is in understanding the knowledge gap between their idea and a judge's or the market's view of a business plan. However, in a curious study reported by Ramsinghani (2011), which studied nonverbal cues such as gestures, expressions and tone, it was predicted with 87 percent accuracy the person who would win a BPC without the judges having read the plans or heard pitches.

Etemad (2004) postulated that the intense and in-depth process of preparing a business plan for competition should enhance participants' perceptions that their venture is highly feasible, and that they possess the requisite entrepreneurial skills to launch the venture. The author links this argument to his study which established a strong correlation between students' perceived capability for new venture success and their experience in BPCs. In the context of starting a new venture, the results of the study indicated that developing a business plan, and having it evaluated by experienced outsiders, is an extremely valuable tool for entrepreneurship students in creating and stimulating an attitude for success.

Unlike human capital, there is no universal definition of social capital. However, the accepted concept around which interest in social capital has developed is that interpersonal relationships matter and provide value to individuals and groups (Bartkus \& Davis, 2010). According to Choo and Bontis (2002), social capital includes the sum of actual and potential resources and assets embedded within, available through, derived from and mobilized in the network of relationship possessed by an individual. Most scholars keep the 
concept simple by defining it as the resources or goodwill that subsists in relationships (Bali, 2005; Bartkus \& Davis, 2010; Boivie, 2008).

In BPCs, social capital includes access to business mentors, access to professional services and free publicity. This is construed from the argument fronted by Tan (2011) that the best way to learn how to be an entrepreneur is to work at the right hand of a successful one. BPCs are designed to bring people together for the purpose of creating a context in which an idea might be developed and tested in a supportive and non-threatening environment (Russell et al., 2008). The professionals involved in a BPC usually consist of a few venture capitalists who give participants excellent guidance on the finer details of a business plan (Hazelgren \& Covello, 2005). Whether the actual relationship is one of coaching or mentoring, it is clear that the 'mentoring' programmes in BPCs provide participants with a range of benefits, which include industry expertise, industry networks, a knowledgeable sounding board, advice and provision of feedback and role models - all of whch would otherwise be unavailable to the entrepreneur (Russell et al., 2008). In the 2009 Kenya National BPC for instance, the finalists were to become members of Enablis Entrepreneurial Network, helping them to enjoy social capital benefits such as mentoring, training and financing opportunities from the network (Mbogo, 2009). Often BPCs add professional services from lawyers, accountants and other advisors as part of the package (Cohan, 2012). According to Strauss (2011), winners in various categories in a BPC might also receive administrative support, incubator space, ongoing business coaching, and legal and other services. Beyond that, the contacts they make often also prove invaluable. In some countries, winners of BPCs manage to rake in $\$ 40,000$ worth of services (Bygrave \& Zacharakis, 2011).

The prospects of raising economic capital is the primary motivation for many contestants in a BPC. Economic capital is defined as capital comprising of fiscal and material wealth that is immediately and directly convertible into money (Bartee \& Brown, 2007). In BPCs, this often manifests in the form of cash awards or cash equivalents and access to potential financiers. In some countries, scholars report testimonies of entrants to BPCs that attracted over a quarter of a million dollars in seed capital (Hewitt, Hewitt, \& D'Abie, 2005). A quick survey of BPCs shows that every year in the United States there are more than 230 BPCs with more than $\$ 9.5$ million awarded to winners of these competitions (Katz, 2012). However, it is not clear from previous studies whether such cash awards translate into enterprise growth. For instance, Lange et al. (2007) in their research claimed that they even knew of students and alums that almost made a career of competing in BPCs; where in one case, the entrepreneur won more than $\$ 100,000$ in at least four BPCs, but four years after the company was founded it had no significant revenue. 
Since judges are typically venture capitalists, a business plan victory signals a stamp of approval that can give company founders an edge when it comes to raising additional capital (Cohan, 2012). Features common to large BPCs include significant corporate sponsorship (Russell et al., 2008). Winners also enjoy free press that help them create awareness about their business. Kantis (2005) suggests that publicity campaigns that accompany BPCs including press conferences, launch events, the printing of pamphlets and other promotional materials, interviews with the media and other activities, have economic value. Strauss (2011) observes that winners in various categories in a BPC get a lot of great press. Entrepreneurs get more respect and goodwill from the business community at large (Abrahms \& Abrams, 2003). The competition, the prizes and the resultant publicity provide the motivation context for the participants (Russell et al., 2008).

\section{Research Methodology}

A quasi experimental research design was used. In order to assess the impact of BPCs on enterprise development, the study compared enterprise development outcomes between the test group and a control group. The target group was the top 100 national finalists who undertook an intensive training at Multimedia University. The test group was the top 100 national finalists who implemented their business plans. The control group was made up of small business owners in Nairobi County who did not participate in the competition thus did not benefit from the BPC. Differences in study groups were controlled using participant matching whereby the respondents' sociodemographic variables such as education, gender and entrepreneurial experience were used as the criteria for matching. A questionnaire method was then used to collect data. The reliability of the instrument was verified through computation of Cronbach's Alpha. The instrument had a Cronbach's alpha of 8.84, suggesting that the instrument was reliable. The instrument was adminitered through telephone interviews, email and face-to-face approach after four years had elapsed since the competition was conducted. Data analysis entailed descriptive statistical techniques which include the computation of the frequencies, mean and standard deviation of the datasets. The relationship between the dependent and independent variables were determined using Spearman's Rank Correlation Coefficient. The data was analysed using SPSS.

\section{Results and Discussions}

Table 1 shows the demographic composition of respondents in the test group (that is, the top 100 national finalists). The researcher made an attempt to collect data from all the top 100 finalists. However, the researcher managed to access 52 finalists. A total of $87 \%$ of the accessible population responded, 
meaning that the response rate was high. The table shows that $71.1 \%$ of the respondents were male whereas $28.9 \%$. Therefore, majority of the top onehundred finalists who participated in this study were male. In terms of education at the time of the competition, $48.9 \%$ of the respondents were university graduates, $37.8 \%$ attained middle level college education and $13.3 \%$ attained secondary level of education. Most (62.2\%) of respondents presented their business plans as sole proprietors, followed by $20 \%$ limited companies and $17.8 \%$ partnerships.

In terms of whether BPC finalists had prior experience running an enterprise at the time of the competition, $60.0 \%$ said yes and $20.0 \%$ said no. Therefore, majority of the respondents had prior experience running a business. However, $80 \%$ of the respondents reported that they did not win a prize whereas only $20 \%$ did win a prize. The table shows that $77.8 \%$ of the respondents implemented their business plans while $22.2 \%$ did not. It was noted that out of the respondents who started their business, eight (28.6\%) of them either implemented a business plan for an entirely new business idea after the exposure they got from the competition or had since shifted into other business sectors.

Table 1 further shows that $34.3 \%$ of the respondents implemented their business plan in the year 2009, 31.4\% of the respondents did so in the year 2010 and $25.7 \%$ of the respondents executed their business plans in the year 2011. Only 5.7\% and $2.9 \%$ of the respondents started their businesses in the year 2012 and 2013, respectively. Therefore, on aggregate, majority $(65.8 \%)$ of the businesses had been in existence for at least three years. Out of the respondents who implemented their business plans, $80.0 \%$ said that their businesses still existed whereas $20.0 \%$ had closed shop. Therefore, majority of the enterprises that were started as a result of the business plan competition were still operational at the time of the study.

Table 1 Demographic Profile of the Top 100 Finalists

\begin{tabular}{|c|c|r|r|}
\hline Variable & Category & Frequency & Percent \\
\hline Gender & Male & 32 & 71.1 \\
\cline { 2 - 4 } & Female & 13 & 28.9 \\
\hline \multirow{2}{*}{$\begin{array}{c}\text { Highest level of education at the } \\
\text { time of competition }\end{array}$} & Secondary education & 6 & 13.3 \\
\cline { 2 - 4 } & Middle level college & 17 & 37.8 \\
\cline { 2 - 4 } & University education & 22 & 48.9 \\
\hline Type of venture & New Venture & 34 & 75.6 \\
\cline { 2 - 4 } & Continuing Venture & 11 & 24.4 \\
\hline Form of ownership & Sole proprietorship & 28 & 62.2 \\
\cline { 2 - 4 } & Partnership & 8 & 17.8 \\
\cline { 2 - 4 } & Limited Company & 9 & 20.0 \\
\hline \multirow{2}{*}{$\begin{array}{c}\text { Prior experience running an } \\
\text { enterprise at the time of } \\
\text { competition }\end{array}$} & Yes & 27 & 60.0 \\
\cline { 2 - 4 } & No & 18 & 40.0 \\
\hline Whether respondent won a prize & Yes & 7 & 20.0 \\
\hline
\end{tabular}




\begin{tabular}{|c|c|r|r|}
\hline & No & 28 & 80.0 \\
\hline \multirow{2}{*}{$\begin{array}{c}\text { Whether respondent implemented } \\
\text { business plan }\end{array}$} & Yes & 35 & 77.8 \\
\cline { 2 - 4 } & No & 10 & 22.2 \\
\hline \multirow{2}{*}{$\begin{array}{c}\text { Year respondent implemented } \\
\text { business plan }\end{array}$} & 2009 & 12 & 34.3 \\
\cline { 2 - 4 } & 2010 & 11 & 31.4 \\
\cline { 2 - 4 } & 2011 & 9 & 25.7 \\
\cline { 2 - 4 } & 2012 & 2 & 5.7 \\
\cline { 2 - 4 } & 2013 & 1 & 2.9 \\
\hline Status of business & Existing & 28 & 80.0 \\
\cline { 2 - 4 } & Closed & 7 & 20.0 \\
\hline
\end{tabular}

Table 2 shows the descriptive statistics of respondents in the control group. The table shows that male respondents accounted for $60 \%$ of the sample in the control group while female respondents were $40 \%$. Nearly half $(48.6 \%)$ of the respondents attained middle level of education with some $25.7 \%$ being university graduates. However, another $25.7 \%$ of the respondents attained secondary education. Similarly, $54.3 \%$ were running sole proprietorships, $34.3 \%$ were partnerships and $11.4 \%$ were limited companies. However, $77.1 \%$ of the respondents in the control group did not have a written business plan whereas $22.9 \%$ were running their businesses based on a written business plan. In terms of year they started business, $31.4 \%$ and $37.1 \%$ of the respondents began their businesses in the year 2009 and 2010 respectively. Some 13.3\% of the respondents started their business in the year 2011 and another 14.3\% began business in the year 2012. Lastly, $11.4 \%$ of the respondents began business in the year 2013 .

Table 2 Demographic Profile of the Control Group

\begin{tabular}{|c|c|c|c|}
\hline Variable & Category & Frequency & Percent \\
\hline \multirow[t]{2}{*}{ Gender } & Male & 21 & 60.0 \\
\hline & Female & 14 & 40.0 \\
\hline \multirow{3}{*}{$\begin{array}{l}\text { Highest level of education at the } \\
\text { time of competition }\end{array}$} & Secondary education & 9 & 25.7 \\
\hline & Middle level college & 17 & 48.6 \\
\hline & University education & 9 & 25.7 \\
\hline \multirow[t]{3}{*}{ Form of ownership } & Sole proprietorship & 19 & 54.3 \\
\hline & Partnership & 12 & 34.3 \\
\hline & Limited Company & 4 & 11.4 \\
\hline \multirow{2}{*}{$\begin{array}{l}\text { Prior experience doing business } \\
\text { before starting the enterprise }\end{array}$} & Yes & 26 & 74.3 \\
\hline & No & 9 & 25.7 \\
\hline \multirow[t]{2}{*}{ Have a written business plan } & Yes & 8 & 22.9 \\
\hline & No & 27 & 77.1 \\
\hline \multirow[t]{5}{*}{ Year started business } & 2009 & 11 & 31.4 \\
\hline & 2010 & 13 & 37.1 \\
\hline & 2011 & 5 & 14.3 \\
\hline & 2012 & 4 & 11.4 \\
\hline & 2013 & 2 & 5.7 \\
\hline
\end{tabular}


Table 3 above shows the descriptive statistics on the business performance of respondents in the top 100 national finalist in the year 2009 business plan competition who implemented their business plans based on four key performance indicators. These are: number of employees, total monthly salaries disbursed and estimated total value of assets of the business. The table shows that in sum, the number of employees at start up was 97, earning a total monthly salary of Ksh.911,000. Over a 4 year period, the total employment had more than doubled to 210, with a total salary of over 4 million shillings disbursed every month. The table also shows that at start up, the total monthly revenue generated by the enterprises of the top 100 national finalists was about 11 million shillings. After four years, the businesses were posting an aggregate of 13.8 million shillings in revenue every month. In terms of total value of assets, the top 100 national finalists started up with just over 2.6 million shillings whereas after the four years, the entrepreneurs reported an estimated aggregate value of assets worth 518 million shillings.

Table 4 also above shows the findings on the performance of enterprises in the control group. For accurate comparison, the business performance of 35 respondents in the control group was represented in the dataset. The table shows that the total number of employees the respondents in the control group started with was 53, earning a total monthly salary of Ksh.883,000. At the time of this study, the number of employees had increased to 91 and the monthly salary disbursement had risen to 3.2 million. In terms of monthly revenue performance, respondents in the control group were posting 1.1 million and at the time of the study, the figure had more than quadrupled to 4.8 million shillings. In total, the respondents estimated the value of their assets at 7.7 million shillings at start up, whereas by the time of the study, they had accumulated 23.6 million worth of business assets.

The study sought to establish whether there was any relationship between BPC variables such as business plan writing skills, pitching and presentation skills, mentorship, networking, increased confidence, publicity and exposure, BPC prize and access to financiers and enterprise growth. Spearman Correlation coefficient was used to determine this relationship, with alpha significant at .05 and .01 levels. Table 5 shows that there was a statistically significant correlation between enterprise growth and: business plan writing skills gained $(r=.407, p<.05)$; mentorship received $(r=.404$, $p<.05)$; network created $(r=.417, p<.05)$ and increase in confidence $(r=.513$, $p<.01)$. However, the relationship between enterprise growth and presentation skills $(r=.282, p>.05)$ as well as access to financiers $(r=.123, p>.05)$ was not statistically significant. The findings suggest that generally, there was a relationship between enterprise growth and PBCs. 
Table 3 Business Performance of the top 100 National Finalists

\begin{tabular}{|c|c|c|c|c|c|c|c|c|}
\hline & $\begin{array}{c}\text { Number of } \\
\text { staff at Start } \\
\text { up }\end{array}$ & $\begin{array}{l}\text { Number of } \\
\text { staff after } 4 \\
\text { years }\end{array}$ & $\begin{array}{c}\text { Total Monthly } \\
\text { Salaries at } \\
\text { Startup } \\
\text { (Ksh) }\end{array}$ & $\begin{array}{l}\text { Total Monthly } \\
\text { Salaries after } \\
4 \text { year (Ksh) }\end{array}$ & $\begin{array}{c}\text { Average } \\
\text { Monthly } \\
\text { Revenue at } \\
\text { Startup (Ksh) }\end{array}$ & $\begin{array}{c}\text { Average Monthly } \\
\text { Revenue after } 4 \\
\text { years (Ksh) }\end{array}$ & $\begin{array}{c}\text { Estimated total } \\
\text { value of assets } \\
\text { at startup } \\
(\mathrm{Ksh})\end{array}$ & $\begin{array}{l}\text { Estimated total } \\
\text { value of assets } \\
\text { after } 4 \text { years } \\
\text { (Ksh) }\end{array}$ \\
\hline Mean & 3 & 7 & 33,740 & 159,462 & 464,791 & 576,416 & 105,480 & $20,724,200$ \\
\hline SD & 4 & 7 & 34,569 & 311,504 & $2,031,462$ & $2,011,495$ & 118,525 & $81,475,938$ \\
\hline Min & 1 & 1 & 0 & 7,000 & 0 & 30,000 & 0 & 0 \\
\hline Max & 20 & 32 & 150,000 & $1,360,000$ & $10,000,000$ & $10,000,000$ & 500,000 & $400,000,000$ \\
\hline Sum & 97 & 210 & 911,000 & $4,305,500$ & $11,155,000$ & $13,834,000$ & $2,637,000$ & $518,105,000$ \\
\hline
\end{tabular}

Table 4 Business Performance of Enterprises in the Control Group

\begin{tabular}{|c|c|c|c|c|c|c|c|c|}
\hline & $\begin{array}{l}\text { Number of } \\
\text { Employees } \\
\text { at Start up } \\
\end{array}$ & $\begin{array}{l}\text { Number of } \\
\text { Employees } \\
\text { Currently } \\
\end{array}$ & $\begin{array}{c}\text { Total Monthly } \\
\text { Salaries at Start } \\
\text { up (Ksh) }\end{array}$ & $\begin{array}{l}\text { Total Monthly } \\
\text { Salaries } \\
\text { Currently (Ksh) } \\
\end{array}$ & $\begin{array}{c}\text { Average } \\
\text { Monthly } \\
\text { Revenue at } \\
\text { Start-up (Ksh) }\end{array}$ & $\begin{array}{c}\text { Average Monthly } \\
\text { Revenue } \\
\text { Currently (Ksh) } \\
\end{array}$ & $\begin{array}{c}\text { Estimated } \\
\text { total value of } \\
\text { assets at start } \\
\text { up (Ksh) }\end{array}$ & $\begin{array}{l}\text { Estimated total } \\
\text { value of assets } \\
\text { currently (Ksh) }\end{array}$ \\
\hline Mean & 2 & 3 & 25,228 & 91,937 & 32,345 & 137,498 & 219,051 & 673,157 \\
\hline SD & 1 & 3 & 20,602 & 117,959 & 35,232 & 195,636 & 544,468 & $1,778,617$ \\
\hline Min & 1 & 1 & 5,000 & 6,500 & 6,000 & 6,900 & 1,500 & 3,000 \\
\hline Max & 4 & 13 & 90,000 & 540,000 & 180,000 & 760,500 & $2,600,000$ & $8,500,000$ \\
\hline Sum & 53 & 91 & 883,000 & $3,217,800$ & $1,132,100$ & $4,812,450$ & $7,666,800$ & $23,560,500$ \\
\hline
\end{tabular}


Table 5 Correlation between BPC Variables and Enterprise Growth

\begin{tabular}{|c|c|c|c|}
\hline & Year 2009 BPC variables & Spearman's Rho & Enterprise growth \\
\hline \multirow[t]{3}{*}{$\overline{1}$} & \multirow[t]{3}{*}{ Business plan writing skills } & Correlation Coefficient & $.407(*)$ \\
\hline & & Sig. (2-tailed) & .015 \\
\hline & & $\mathrm{N}$ & 35 \\
\hline \multirow[t]{3}{*}{2} & \multirow{3}{*}{$\begin{array}{l}\text { Pitching and presentation } \\
\text { skills }\end{array}$} & Correlation Coefficient & .282 \\
\hline & & Sig. (2-tailed) & .101 \\
\hline & & $\mathrm{N}$ & 35 \\
\hline \multirow[t]{3}{*}{3} & \multirow[t]{3}{*}{ Mentorship } & Correlation Coefficient & $.404(*)$ \\
\hline & & Sig. (2-tailed) & .016 \\
\hline & & $\mathrm{N}$ & 35 \\
\hline \multirow[t]{3}{*}{4} & \multirow[t]{3}{*}{ Networking } & Correlation Coefficient & $.417(*)$ \\
\hline & & Sig. (2-tailed) & .013 \\
\hline & & $\mathrm{N}$ & 35 \\
\hline \multirow[t]{3}{*}{5} & \multirow[t]{3}{*}{ Increased confidence } & Correlation Coefficient & $.513(* *)$ \\
\hline & & Sig. (2-tailed) & .002 \\
\hline & & $\mathrm{N}$ & 35 \\
\hline \multirow[t]{3}{*}{6} & \multirow[t]{3}{*}{ Publicity and exposure } & Correlation Coefficient & $.594(* *)$ \\
\hline & & Sig. (2-tailed) & .000 \\
\hline & & $\mathrm{N}$ & 35 \\
\hline \multirow[t]{3}{*}{7} & \multirow[t]{3}{*}{ Access to financiers } & Correlation Coefficient & .123 \\
\hline & & Sig. (2-tailed) & .488 \\
\hline & & $\mathrm{N}$ & 35 \\
\hline
\end{tabular}

* Correlation is significant at the 0.05 level (2-tailed).

** Correlation is significant at the 0.01 level (2-tailed).

\section{Discussions}

Characteristic of all BPCs obviously is human capital development due to training in various aspects of the planning phase of a new and/or expanding business venture. This training is intended at least to lead to the creation and growth of successful new businesses, where success is partly measured by staying in business. The findings of this study showed that due to their participation in the BPC, nearly all of the respondents agreed that they acquired valuable skills and experience while writing their business plans which they continued to apply in their businesses. The results agree with Russell et al.'s (2008) findings in their study of the impact of BPCs in Australia where they established that the competitions have the potential to, among others, enhance the education experience of the participants by developing entrepreneurial skills. A raft of these skills have been previously identified by scholars such as Skogen and Sjovoll (2010) who argued that the educational content in BPCs expose participants to the process from general idea to business idea, and an array of other business skills including market mapping and analysis, economic understanding, the use of various resources 
and sources of capital, risk assessment, marketing and market planning, competition, customer service, ethical issues, organization and formal rules connected with establishing and running a business.

The results of this study showed that on average, each participant in the 2009 Kenya national BPC represented in this study employed more than twice the number of employees reported by non-participants, disbursed nearly double the average total monthly salaries disbursed by non-participants, generated average monthly sales revenue that quadrupled the average sales revenue reported by non-participants, and accumulated assets worth several times the value of assets accumulated by non-participants. In many ways, these findings consolidate the importance of a business plan as a planning tool and a roadmap to success as argued by many scholars including Fiore (2005), Skogen and Sjovoll (2010) and Barrow (2011). The findings however contradicts the results of a study by Lange et al. (2007) which found that writing a business plan before a business began operating made no difference to the subsequent revenue, net income and number of employees. While reasons for this may call for further empirical enquiry, perhaps the dynamics of enterprise development varied beyond the factors considered in this study.

Networking is one of the most common advantages mentioned by both scholars and industry practitioners as the business case for promoting BPCs as noted in the works of Hewitt et al. (2005), Landstrom et al. (2008) and Strauss (2011). In this study, majority of the participants in the 2009 Kenya National BPC who implemented their business plans agreed that their participation in the competition enabled them to network with various experts who offered them the professional services they would not have received otherwise. This finding reflects the concept of social capital as a valid theoretical paradigm, rightly situated in what Hauberer (2010) construed as a relationship immanent capital that provides useful support when it is needed. This study found that networking as a variable had the second highest correlation coefficient in terms of its relationship with enterprise growth, thereby, further confirming the validity of social capital theory. Clearly, social capital is important to economic growth seen by its proponents like Hohmann and Welter (2005) as an informal institution that serves as a new production factor. That the relationship between networking and enterprise growth was statistically significant is consistent with a past empirical study reported by Etemad and Wright (2003) which also found strong support for social capital theory as being one of the important factors for business success.

The crucial role played by social capital is resonated by additional findings which showed that most of the participants in the 2009 Kenya National BPC would like individual mentoring as well as follow up of each individual participant to see how they are fairing on after the competition. This finding underscores the perspective of Tan (2011) who argued that company- 
building is not an innate ability and as such, the best way to learn how to be an entrepreneur is to work at the right hand of a successful one. According to Hazelgren and Covello (2005), the professionals involved in a BPC usually consist of a few venture capitalists who give participants excellent guidance on the finer details of a business plan. It can thus correctly be inferred, in harmony with the observations of Russell et al. (2008), that BPCs are designed to bring people together for the purpose of creating a context in which an idea might be developed and tested in a supportive and non-threatening environment.

This study also established that majority of the respondents agreed that the goodwill, publicity and exposure they gained from the competition enabled them to get customers and expand their business contacts. This agrees with Abrahams and Abrahams' (2003) observation that entrepreneurs get more respect and understanding from the business community at large. For instance, one of the respondents in this study revealed that the very fact that he emerged among the top 100 national finalists and having been awarded a certificate made him to secure support from a local politician in his county who later replicated his business concept to a group of youth in the County. BPCs therefore stimulate the acquisition of social capital in very unique ways whose multiplier effects on enterprise development and economic growth can be far reaching.

\section{Conclusion}

Business plan competitions help develop the human capital needed by entrepreneurs to create and manage successful enterprises whose performance exceeds the performance of the average enterprise. Participants acquire advanced enterprise development skills and experience during the process of writing their business plans which is unavailable to non-participants. This is because they are trained by industry experts who are themselves successful entrepreneurs and professionals in their respective fields and business sectors. By the end of such competitions, participants step out into the marketplace with the competence and confidence needed to launch and run a successful business. The exposure they get builds on their entrepreneurial self-efficacy, energizing and challenging them to execute business ideas with impressive results evident, among others, by the number of enterprises created and sustained, the number of jobs created, income generated and assets accumulated.

The social capital created by business plan competitions also translates into tangible bottom-line results to participants. The competition enables participants to network with various experts who offer them free professional services they would not otherwise afford. This makes the potential in the social capital available to participants in business plan competitions a uniquely 
valuable production factor that contributes to business success. Through mentorship in the course of the competition, participants access heterogeneous knowledge domains that otherwise would be unavailable. Armed with this knowledge, the entrepreneurs have a significant head-start over nonparticipants. For example, the goodwill, publicity and exposure they gain from the competition enable them to get customers and rapidly expand their business contacts as they get more respect and understanding from the business community at large.

The potential access to economic capital plays an insignificant role in enterprise development outcome of BPCs as most participants hardly get funded if at all. This may be the case because of three reasons. Firstly, little follow up that can lead to the exploitation of this potential is made by organizers and participants alike. This is potentially attributable in part to the discouragement that participants who do not win a prize experience. Secondly, it is common knowledge that formal financial institutions often impose stringent requirements that most start-ups are unable to satisfy. Thirdly, the cost of making follow ups due to the logistics of travelling and physical communication from far flung areas to chase for funding is a potential barrier to participants, most of whom lack the financial wherewithal.

In a nutshell, the value for money invested in BPCs is quite evident from the study. The managerial and policy implication is that a basis is provided for justifying future resource allocation and further continuance of BPCs across the country. The practical application of this research rests in the development of a BPC model that adapts and improves on the framework used by ChoraBizna Enablis LaunchPad.

In terms of theory development, the study provides empirical proof for human capital and social capital theories but not economic capital dimensions as important antecedents to enterprise development. It is nevertheless argued here that BPC prizes are important incentives without which, such events would lose their attractiveness.

Given the compelling enterprise development dividends accruing from BPCs to participants and the society, more such competitions should be held. Increasing the frequency, quality, quantity and scope of the competitions is a worthwhile investment towards empowering a nation. Future studies should test the efficacy of BPCs for enterprise development as a tool for empowering among people with disabilities.

\section{References:}

1. Abrams, R. \& Abrams, M. (2003). The Successful Business Plan: Secrets \& Strategies. Palo Alto: The Planning Shop. 
2. Audretsch, B. D., Grilo, I. \& Thurik, A. R. (2007). Handbook of Research on Entrepreneurship Policy. Cheltenham: Edward Elgar Publishing.

3. Audretsch, D. B. (2002). Entrepreneurship: Determinants and Policy in a European-U.S. Comparison. New York: Springer Publishers.

4. Bali, R. K. (2005). Clinical Knowledge Management: Opportunities and Challenges. Calgary: Idea Group Inc.

5. Barrow, C. (2011). The 30 Day MBA in Marketing: Your Fast Track Guide to Business Success. London: Kogan Page Publishers.

6. Bartee, R. D. \& Brown, M. C. (2007). School Matters: Why African American Students Need Multiple Forms of Capital. Bern: Peter Lang.

7. Bartkus, V. O. \& Davis, J. H. (2010). Social Capital: Reaching Out, Reaching In. Cheltenham: Edward Elgar Publishing.

8. Boivie, S. R. (2008). Determinants and Consequences of Board-level Human and Social Capital. New York: ProQuest.

9. Bowen, M., Morara, M. \& Mureithi, S. (2009). Management of Business Challenges among Small and Micro Enterprises in NairobiKenya. KCA Journal of Business Management, 2(1), 16-31.

10. Bygrave, W. D. \& Zacharakis, A. (2011). Entrepreneurship. New York: John Wiley \& Sons.

11. Choo, C. W. \& Bontis, N. (2002). The Strategic Management of Intellectual Capital and Organizational Knowledge. Oxford: Oxford University Press.

12. Cohan, P. S. (2012). Hungry Start-up Strategy: Creating New Ventures with Limited Resources and Unlimited Vision. San Francisco: BerrettKohler Publishers.

13. Crainer, S. \& Dearlove, D. (2000). Generation Entrepreneur: Shape Today's Business Reality, Create Tomorrow's Wealth, Do Your Own Thing. Upper Saddle River: FT Press.

14. Diana, L. P. (2007). Handbook of Research on Ethnic Minority Entrepreneurship: A Co-evolutionary View on Resource Management. Cheltenham: Edward Elgar Publishing.

15. Durr, M. \& Hill, S. A. (2006). Race, Work, and Family in the Lives of African Americans. Lanham: Rowman \& Littlefield.

16. Etemad, H. (2004). International Entrepreneurship in Small and Medium Size Enterprises: Orientation, Environment and Strategy. Cheltenham: Edward Elgar Publishing.

17. Fayolle, A. \& Klandt, H. (2006). International Entrepreneurship Education: Issues and Newness. Cheltemham: Edward Elgar Publishing.

18. Fayolle, A. \& Torodov, K. (2011). European Entrepreneurship in the Globalizing Economy. Cheltenham: Edward Elgar Publishing. 
19. Fayolle, A. (2010). Handbook of Research in Entrepreneurship Education: International Perspectives. Cheltenham: Edward Elgar Publishing.

20. Gachiri, J. (2009). Lack of Business Plans Stifle growth of SMEs, says experts and State officials. Business Daily. [Online] Available: http://www.businessdailyafrica.com

21. Greene, C. L. (2011). Entrepreneurship: Ideas in Action: Ideas in Action. New York: Cengage Learning.

22. Gumpert, D. E. (2003). Burn your business plan!: what investors really want from entrepreneur. Needham: Lauson Publishing.

23. Hazelgren, B. J. \& Covello, J. A. (2005). Your First Business Plan: A Simple Question and Answer Format Designed to Help You Write Your Own Plan. Naperville: Sourcebooks, Inc.

24. Henke, T., Fernau, M. L., Lueck, L. A. \& Burke, B. (2012). Entrepreneurial Impact: The Rice BPC: 2001-2012. [Online] Available: http://alliance.rice.edu/uploadedFiles/.../ImpactReport.pdf

25. Hewitt, L., Hewitt, A. \& D'Abadie, L. (2005). The Power of Focus for College Students. Deerfield Beach: HCI.

26. House-Soremenkun, B. \& Falola, T. (2011). Globalization and Sustainable Development in Africa. Rochester: University Rochester Press.

27. Hulsink, W. \& Dons, H. J. M. (2008). Pathways to High-Tech Valleys and Research Triangles: Innovative Entrepreneurship, Knowledge Transfer and Cluster Formation in Europe and the United States. New York: Springer Publishers.

28. International Labour Office (2008). Skills for Improved Productivity, Employment Growth and Development: Fifth Item on the Agenda. Geneva: International Labour Organization.

29. Jaishankar, K. (2009). International Perspectives on Crime and Justice. Tamil Nadu: K. Jaishankar Publications.

30. Kantis, H. (2005). Developing Entrepreneurship: Experience in Latin America and Worldwide. Newark: IDB.

31. Kaputa, C. (2012). Breakthrough Branding: How Smart Entrepreneurs and Intrapreneurs Transform a Small Idea into a Big Brand. London: Nicholas Brealey Publishing.

32. Katz, J. A. (2012). Entrepreneurial Action. Bradford: Emerald Group Publishing.

33. Kelley, D. \& Thomas, H. (2011). Entrepreneurship Education in Asia. Cheltenham: Edward Elgar Publishing.

34. Kenya Institute of Management (2012). Jitihada II: Kenya's National BPC 2011-2012. [Online] Available: http://www.kim.ac.ke/jitihada/documents/Jitihada\%20Brochure.pdf 
35. Landstrom, H. \& Lohrke, F. (2010). Historical Foundations of Entrepreneurial Research. Cheltenham: Edward Elgar Publishing.

36. Landstrom, H., Crijns, H., Laveren, E. \& Smallbone, D. (2008). Entrepreneurship, Sustainable Growth and Performance: Frontiers in European Entrepreneurship Research. Cheltenham: Edward Elgar Publishing.

37. Lange, J. E. J., Mollov, A., Pearlmutter, M., Singh, S. \& Bygrave, W. D. (2007). Pre-start-up Formal Business Plans and Post-start-up Performance: A Study of 116 New Ventures. Venture Capital, (9) 4, $237-256$.

38. Leadbeater, C. \& Oakley, K. (2001). Surfing the Long Wave: Knowledge Entrepreneurship in Britain. New York: Demos.

39. Letting, L. \& Muthoni, M. (2013). Innovation through Business Planning among Micro, Small and Medium Enterprises in Kenya. Nairobi: University of Nairobi. Retrieved on $2^{\text {nd }}$ October 2013 from http://erepository.uonbi.ac.ke:8080/xmlui/handle/123456789/39630?s how $=$ full

40. Libecap, G. D. (2009). Frontiers in Eco-entrepreneurship Research. Bingley: Emerald Group Publishing.

41. London, T., Hart, S. L. \& Kacou, E. (2011). Business Strategies for the Bottom of the Pyramid. Upper Saddle River: FT Press.

42. Mbogo, S. (2009). Medical Records Plan Wins Business Contest. Business Daily. [Online] Available: http://www.businessdailyafrica.com

43. Njogu, K. (2013). Youth and Peaceful Elections in Kenya. Oxford: African Books Collective.

44. OECD (2010). Higher Education in Regional and City Development Higher Education in Regional and City Development: Berlin, Germany 2010. Paris: OECD Publishing.

45. Otuki, N. (2013). Budding investors bag Sh3m in BPC. Business Daily. [Online] Available: http://www.businessdailyafrica.com

46. Pakroo, P. H. (2012). The women's small business start up kit: a stepby-step legal guide. Berkeley: Nolo Publishers.

47. Rabb, C. (2009). Invisible Capital: How Unseen Forces Shape Entrepreneurial Opportunity. San Francisco: Berrett-Koehler Publishers.

48. Ramsinghani, M. (2011). The Business of Venture Capital: Insights from Leading Practitioners on the Art of Raising a Fund, Deal Structuring, Value Creation, and Exit Strategies. New York: John Wiley \& Son.

49. Reddi, N. C. V. (2009). Effective Public Relations and Media Strategy. New Delhi: PHI Learning Pvt. Ltd. 
50. Riviezzo, A., De Nisco, A. \& Napolitano, M. R. (2012). Entrepreneurship Higher Education in Europe: State of the Art and Marketing Insights to Enhance the Attraction of Foreign Students. Munchen: GRIN Verlag.

51. Rosseau, D. M. (2012). The Oxford Handbook of Evidence-based Management. Oxford: Oxford University Press.

52. Russell, R., Atchison, M. \& Brooks, R. (2008). BPCs in tertiary institutions: encouraging entrepreneurship education. Journal of Higher Education Policy and Management, 30 (2), 123-138.

53. Schwerdtfeger, P. (2011). Marketing Shortcuts for the Self-Employed: Leverage Resources, Establish Online Credibility and Crush Your Competition. New York: John Wiley \& Sons.

54. Smith-Hunter, A. (2006). Women Entrepreneurs across Racial Lines: Issues of Human Capital, Financial Capital and Network Structures. Cheltenham: Edward Elgar Publishing.

55. Stevenson, L. (2010). Private Sector and Enterprise Development: Fostering Growth in the Middle East and North Africa. Ottawa: IDRC.

56. Strauss, S. D. (2011). Get Your Business Funded: Creative Methods for Getting the Money You Need. New York: John Wiley \& Sons.

57. Tan, Y. (2011). Chinnovation: How Chinese Innovators are changing the World. New York: John Wiley \& Sons.

58. Taylor, S. D. (2012). Globalization and the Cultures of Business in Africa: From Patrimonialism to Profit. Bloomington: Indiana University Press.

59. Wankel, C. (2010). Cutting-edge Social Media Approaches to Business Education: Teaching with LinkedIn, Facebook, Twitter, Second Life, and Blog. Charlotte: IAP.

60. Welsch, H. P. (2003). Entrepreneurship: The Way Ahead. London: Routledge.

61. Wong, P. K. (2011). Academic Entrepreneurship in Asia: The Role and Impact of Universities in National Innovation Systems. Cheltenham: Edward Elgar Publishing.

62. Zhang, L. \& Zhang, C. (2011). Engineering Education and Management. New York: Springer Publishers. 